\title{
Association of Dopamine Beta-Hydroxylase Polymorphisms with Alzheimer's Disease, Parkinson's Disease and Schizophrenia: Evidence Based on Currently Available Loci
}

\author{
Siqi Tanga,b Bin Yao a,b Na Lia, Shuhuang Lin ${ }^{a, b} \quad$ Zunnan Huang ${ }^{a, d}$ \\ aKey Laboratory for Medical Molecular Diagnostics of Guangdong Province, Dongguan Scientific \\ Research Center, Guangdong Medical University, Dongguan, 'The Second School of Clinical Medicine, \\ Guangdong Medical University, Dongguan, 'School of Pharmacy, Guangdong Medical University, \\ Dongguan, IInstitue of Marine Biomedical Research, Guangdong Medical University, Zhanjiang, China
}

\section{Key Words}

Dopamine beta-hydroxylase - Alzheimer's disease - Parkinson's disease - Schizophrenia • Neurodegenerative diseases $•$ Polymorphism • Meta-analysis

\begin{abstract}
Background/Aims: The neuropathies Alzheimer's disease (AD), Parkinson's disease (PD), and schizophrenia (SCZ) have different pathological mechanisms but share some common neurodegenerative features, such as gradual loss of neuronal structure and function. Dopamine beta-hydroxylase $(\mathrm{DBH})$, a gene located in the chromosomal region 9q34, plays a crucial role in the process of converting dopamine into norepinephrine (NE). Several case-control studies have reported this pathway in the pathogenesis of $A D, P D$ and SCZ. However, the results are controversial. Methods: We conducted a meta-analysis to estimate the associations between polymorphisms in this gene and AD, PD and SCZ. Seven databases (PubMed, Embase, Web of Science, China National Knowledge Infrastructure (CNKI), Wan Fang, SZ Gene and AD Gene) were searched to identify eligible studies. Odds ratios (ORs) with $95 \%$ confidence intervals $(\mathrm{Cls})$ were calculated to evaluate the associations of $\mathrm{DBH}$ variants with $\mathrm{AD}, \mathrm{PD}$ and SCZ susceptibility. Results: A total of 41 studies involving 10506 cases and 15083 controls were included in our meta-analysis. The analysis results indicated that a lack of association $(P>$ 0.05 ) was observed between most of the currently available DBH polymorphisms and the neurological diseases AD, PD and SCZ; however, the DBH rs 1611131 (allelic model: OR = $0.889,95 \%$ Cl: $0.815-0.969$; dominant model: $\mathrm{OR}=0.868,95 \% \mathrm{Cl}: 0.778-0.968)$, rs22283123 (allelic model: $\mathrm{OR}=0.285,95 \% \mathrm{Cl}: 0.095-0.862$; dominant model: $\mathrm{OR}=0.290,95 \% \mathrm{Cl}: 0.094-$ 0.897 ) and rs2007153 (allelic model: $\mathrm{OR}=2.196,95 \%$ Cl: $1.506-3.200 ;$ dominant model: OR = 2.985, 95\% Cl: 1.465 - 6.084; recessive model: $\mathrm{OR}=2.729,95 \% \mathrm{Cl}: 1.548-4.812$ ) variants were

S. Tang and B. Yao contributed equally to this work.

Zunnan Huang and Shuhuang Lin

Key Laboratory for Medical Molecular Diagnostics of Guangdong Province, Guangdong Medical University,

No. 1 Xincheng Road, Songshan Lake District, Dongguan 523808 (China)

Tel. +86 13925590670; +86 13537173909, E-Mail zn_huang@yahoo.com; shuhuang_lin@yahoo.com
\end{abstract}




\section{Cellular Physiology Cell Physiol Biochem 2018;51:411-428

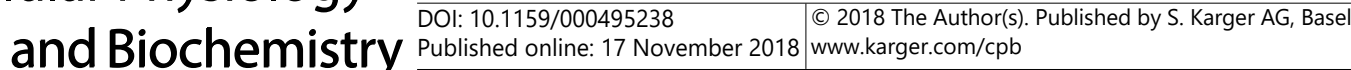 \\ Tang et al.: DBH Polymorphisms and Alzheimer's Disease, Parkinson's Disease and \\ Schizophrenia}

shown to be significantly associated with the risk of $A D$ (the former variant) and SCZ (the latter two variants). Conclusion: On the one hand, most DBH polymorphisms from the currently available loci showed no linkage to $A D, P D$ or $S C Z$, indicating the lower possibility of these loci serving as genetic markers of the risks of diseases with neurodegenerative characteristics. On the other hand, the DBH rs2283123 and rs2007153 polymorphisms could have opposite effects on SCZ development in Caucasians and be more specific in Croatians, while the DBH rs1611131 minor variant might have a protective effect on AD risk in Caucasians; however, these results require further study.

(C) 2018 The Author(s)

Published by S. Karger AG, Basel

\section{Introduction}

Alzheimer's disease (AD), Parkinson's disease (PD) and schizophrenia (SCZ) all have neurodegenerative characteristics, and although they all show different pathogenies and diseased regions, they each result from the gradual loss of neuronal structure and function or even neuronal death [1]. Illustratively, AD is characterized by the loss of neurons and synapses in the cerebral cortex and certain subcortical regions, including the temporal lobe, regions of the frontal cortex, the cingulate gyrus and the locus coeruleus (LC) in the brainstem [2]; PD is pathologically represented by a degeneration of dopaminergic neurons in the substantia nigra and noradrenergic neurons in the LC [3]; and SCZ is a mental disease that manifests as gradual atrophy of the temporal and parietal lobe as well as enlargement of ventricular regions [4]. Such diseases cause enormous damage to patients' cognitive and behavioral functions [5-7], which seriously reduces their quality of lives. Approximately 29.8, 6.2, and 23.6 million people are estimated to develop AD, PD and SCZ per year, respectively [8, 9]. Although the mechanisms of these three diseases remain unclear, studies have demonstrated that they have common genetic backgrounds and share multiple environmental risk factors. More recently, genome-wide association studies (GWAS) and sequencing approaches have been widely used to discover low-frequency disease risk alleles, and thousands of susceptibility loci might predispose individuals to multiple neurodegenerative diseases [10]. An expected observation for risk variants is shared across diseases. Several genes are associated with $\mathrm{AD}, \mathrm{PD}$ and SCZ and are included in the shared dopamine (DA) system network, including monoamine oxidase A (MAOA) [11-12], monoamine oxidase B (MAOB) [13-16], catechol0-methyltransferase (COMT) [17-19] and dopamine beta-hydroxylase (DBH) [20-24]. Identification of these loci could help us better understand the mechanisms underlying the development of and cognitive dysfunction in AD, PD, and SCZ and provide biomarkers for their risk of susceptibility.

The dopamine beta-hydroxylase (DBH) protein is a member of the DA system, which catalyzes the oxidative hydroxylation of DA to norepinephrine (NE) [25]. The enzyme DBH is specifically expressed by noradrenergic neurons, including those in the $\mathrm{LC}$ and peripheral nerve terminals [26]. Existing in both soluble and membrane-bound forms, DBH is the only catecholamine synthetase that is expressed in synaptic vesicles [25]. The enzymatic activity of DBH modulates NE levels and further influences executive and motor function as well as reward perception in humans [22], characterized by wide interindividual variation regulated by genetic inheritance [27]. The DBH gene, located in the chromosomal region 9q34 and also known as dopamine beta-monooxygenase (DBM), has an approximately $23 \mathrm{~kb}$ sequence that comprises 12 exons.

Because the DBH enzyme plays a key role in the metabolism of DA and NE in the central nervous system (CNS), mutations in its sequence might participate in progressive structural or functional neuronal damage, ultimately resulting in neurodegenerative disease. Thus, it can be logically hypothesized that single nucleotide polymorphisms (SNPs) of DBH could be genetic markers of the risks of AD, PD and SCZ. Many GWAS and case-control studies have investigated the relationship of DBH polymorphisms with these three diseases, and it was even reported that DBH polymorphisms, such as variations in exons of rs1108580, rs5320, 


\section{Cellular Physiology Cell Physiol Biochem 2018;51:411-428

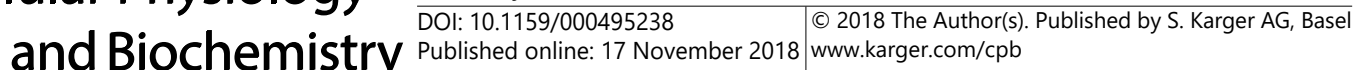 Tang et al.: DBH Polymorphisms and Alzheimer's Disease, Parkinson's Disease and Schizophrenia}

MspI, and rs4531 and introns of 5'-Ins/Del, rs1611115, rs1611131, and rs2519152, could play a role in the pathophysiologies of AD [20-24], PD [28-33] and SCZ [34-49].

Available studies have reported relationships between DBH polymorphisms and the risk of developing AD, PD and SCZ with discrete data, controversial conclusions and insufficient sample sizes. For example, Healy D.G. et al. first reported that the DBH rs1611115 TT genotype genetically determined low serum DBH activity and protected against PD among a United Kingdom (UK) Caucasian population in 2004 [29], whereas two reproductive studies by Chun L.S. et al. in 2007 and Ross O. et al. in 2008 showed no evidence of association between this polymorphism and PD susceptibility [28, 30]; however, a recent genetic association research by Shao P. et al. in 2016 indicated that the TT genotype may lead to a higher risk of PD occurrence than the common genotype CC [31]. Conflicting results have also been published on variations of DBH rs2519152 [31] and other loci [29,31].

To date, no systematic reviews or meta-analyses of these associations have been conducted to address the issues of inconsistency, insufficiency, and especially nonsystematicness. Thus, we obtained available evidence from all previously published studies concerning the association between DBH SNPs and susceptibility to AD, PD and SCZ and carried out a metaanalysis to estimate this genetic relationship association.

\section{Materials and Methods}

\section{Search strategies}

Two reviewers systematically searched literature from the PubMed, Embase, Web of Science, China National Knowledge Infrastructure (CNKI), Wan Fang, SZ Gene (http://www.SZgene.org) and AD Gene (http://www.ADgene.org) databases with no language restrictions through January $14^{\text {th }}, 2018$ using the keywords Alzheimer Disease, Parkinson Disease, Schizophrenia, Dopamine beta-hydroxylase, Polymorphism, etc.. Detailed search strategies are reported in the supplementary materials (For all supplemental material see www.karger.com/d10.1159/000495238). An additional manual search was performed according to references cited in the original literatures or previous reviews.

\section{Literature identification}

The suitable studies were selected based on the following inclusion criteria: (I) studies assessing the association of DBH polymorphisms with risks of AD, PD or SCZ; (II) original studies performed using a casecontrol or cohort design and involving human subjects; (III) studies providing sufficient allelic (e.g., W and M) or genotypic (e.g., WW, WM and MM) data that contained controls with genotypes in Hardy-Weinberg equilibrium (HWE). Studies that did not meet the above inclusion criteria were excluded from our metaanalysis.

\section{Data extraction}

For eligible studies, the following data were extracted: (I) the first author's name and publication year; (II) the geographic areas, ethnicities and ages of the participants; (III) the numbers of cases and controls in populations carrying different allelic or genotype statuses; and (IV) the diagnostic criteria for AD, PD or SCZ used in the studies. This step was independently completed by two reviewers. Any disagreement was resolved by discussion with a third reviewer. For studies with overlapping data, that with the largest sample size was included in this meta-analysis.

\section{Methodological quality assessment}

Newcastle-Ottawa Scale (NOS) criteria were used to assess the quality of the retrieved studies, which included three aspects: object selection, comparability and exposure assessment [50]. Studies with at least six points were considered high-quality.

\section{Statistical analyses}

For each study included in this meta-analysis, the $\chi^{2}$ test was used to detect whether the observed genotype frequencies among the control groups conformed to Hardy-Weinberg equilibrium (HWE). A $\chi^{2}$ 


\section{Cellular Physiology Cell Physiol Biochem 2018;51:411-428 \begin{tabular}{l|l|l} 
and Biochemistry Published online: 17 November 2018 & $\begin{array}{l}\text { (c) } 2018 \text { The Author(s). Published by S. Karger AG, Basel } \\
\text { www.karger.com/cpb }\end{array}$ \\
\hline
\end{tabular} \\ Tang et al.: DBH Polymorphisms and Alzheimer's Disease, Parkinson's Disease and \\ Schizophrenia}

test $P$ value greater than 0.05 suggested that the study sample was representative of the population in the corresponding area.

Odds ratios (ORs) with 95\% confidence intervals (CIs) were utilized as effect sizes to evaluate the strengths of the associations between the DBH polymorphisms and risks of AD, PD and SCZ under three genetic models: (I) the allelic model (M vs. W), (II) the dominant model (MM+WM vs. WW), and (III) the recessive model (MM vs. WM+WW). Subgroup analysis was performed to confirm their associations among different ethnicities.

Between-study heterogeneity was assessed by the $I^{2}$ statistic from the $\chi^{2}$-based Q test [51]. If $I^{2}<$ $50 \%$, the fixed-effect model (Mantel-Haenszel method) would be applied to calculate the pooled OR (for pooled estimation) [52]. Otherwise, the random-effects model (DerSimonian-Laird method) was employed to complete this work [53]. Once significant heterogeneity was found, meta-regression [54] would be performed based on the potential confounding factors, including the year, language, ethnicity, diagnose criteria, etc., to determine the source of heterogeneity observed.

For loci with more than three datasets, sensitivity analysis was performed to detect whether the results were considerably influenced by any single study. Simultaneously, Begg's funnel plots constructed by the trim and fill method and quantitative tests were used to estimate publication bias in the included studies.

All analyses were performed using STATA version 14.0 software (STATA Corporation, College Station, TX, USA) with the metan command [55].

\section{Results}

\section{Literature search results}

Fig. 1 shows a flow chart describing the procedure used to select the eligible studies included in our analysis. The comprehensive search strategy initially identified 429 potential articles (AD: $n=55$, PD: $n=126$, SCZ: $n=248$ ). Among them, 97 studies were duplicates (AD: $n$ $=8$, PD: $\mathrm{n}=20$, SCZ: $\mathrm{n}=69$ ). After removing these duplicates, 332 publications were retained (AD: $n=47$, PD: $n=106$, SCZ: $n=179$ ), including 153 (AD: $n=26$, PD: $n=73$, SCZ: $n=54$ ) articles on unrelated genes and 119 (AD: $n=14$, PD: $n=15$, SCZ: $n=90$ ) articles whose studies did not utilize a case-control or cohort design. Thus, these 272 studies were excluded, and 60 publications remained (AD: $n=7, P D: n=18, S C Z: n=35$ ). Among the remaining 60 articles, 31 (AD: $n=1$, PD: $n=11$, SCZ: $n=19$ ) lacked sufficient allelic or genotypic data. Detailed genotype data were used for the HWE test, and two studies (AD: $\mathrm{n}=1$, PD: $\mathrm{n}=1$, SCZ: $\mathrm{n}=0$ ) were excluded because they were not in equilibrium. Finally, 27 articles, including 41 eligible studies, were included in this metaanalysis: 7 studies on AD [20-24], 7 studies on PD [28-33] and 27 studies on SCZ [34-49].

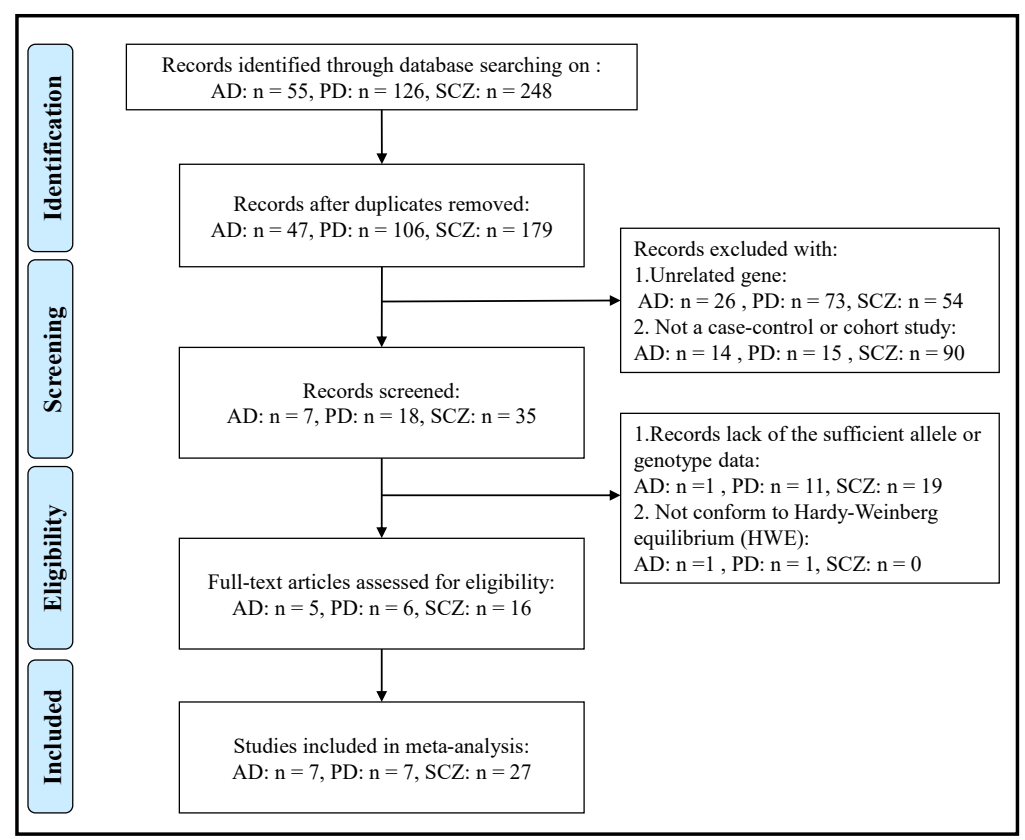

Fig. 1. Flow diagram of the process used to select eligible studies. 


\section{Cellular Physiology Cell Physiol Biochem 2018;51:411-428

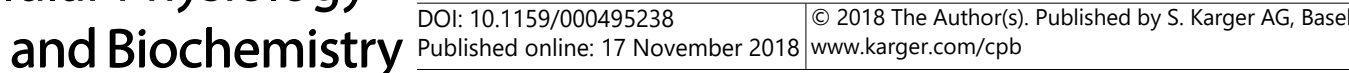 Tang et al.: DBH Polymorphisms and Alzheimer's Disease, Parkinson's Disease and Schizophrenia}

Main characteristics of the included studies

Table 1 presents the main characteristics of the 41 studies utilized in this metaanalysis. These studies were published from 1996 to 2016 . Among them, 25 studies involved Caucasian populations (AD: $\mathrm{n}=5$ [20-22], PD: $\mathrm{n}=3$ [28-30], SCZ: $\mathrm{n}=17$ [34-37, 44-46, 48]), and 16 studies involved Asian populations (AD: $\mathrm{n}=2$ [23, 24], PD: $\mathrm{n}=4$ [31-33], SCZ: $\mathrm{n}=$ 10 [38-43, 47, 49]). Additionally, two diagnostic criteria were used among the AD studies included (DSM-IV [56] and NINCDS-ADRDA [57]), two criteria were used for PD studies (UK PD Society Brain Bank Clinical Diagnostic Criteria (UK-PDSBB) [58] and Standard for Second National conference on Cone Diseases), and three criteria were used for SCZ studies (DSM-IV [56], DSM-III-R [56] and ICD-10 [59]). Using the methodological quality assessment according to NOS, all the included studies had scores greater than six and were considered high-quality (Table 2). Detailed genotype data from each original study are shown in Table S1.

\section{Association between $D B H$ and $A D$}

In this meta-analysis, a total of seven studies involving 2618 cases and 6849 controls, including five for rs1611115 [20-24], one for rs5320 and one for rs1611131 [20], were collected to investigate the association between $\mathrm{DBH}$ polymorphisms and AD development. Combined data revealed that the collection of DBH polymorphisms was not statistically significantly associated with the risk of AD under any of the three genetic models (allelic model: $P=0.714$, dominant model: $P=0.837$, and recessive model: $P=0.607$ ). The results of these three genetic comparisons also indicated a lack of statistical association between the rs1611115 polymorphism (allelic model: $P=0.132$, dominant model: $P=0.146$, and recessive model: $P=0.425$ ) and susceptibility to AD (Fig. 2a and Table 3). Subgroup analysis by ethnicity further suggested no association between this polymorphism and AD in either Caucasian or Asian populations (Table 4). In addition, the other two loci presented in only one study each; the DBH rs5320 polymorphism showed no relationship with AD (allelic model: $P=0.252$, dominant model: $P=0.298$, and recessive model: $P=0.394$ ), while the DBH rs1611131 polymorphism was suggested to be statistically associated with a decreasing risk of AD under the allelic (OR $=0.889,95 \% \mathrm{CI}: 0.815-0.909, P=0.008)$ and dominant (OR $=0.868,95 \%$ CI: $0.778-0.968, P=0.011)$ models but not under the recessive $(P=0.118)$ model. In summary, the above results indicate that while minor variants of rs1611131 might play a protective role in AD development, no associations of the rs1611115 or rs5320 polymorphisms as well as the combination of all three DBH loci with AD risks were observed.

\section{Association between $D B H$ and $P D$}

A meta-analysis of the association between DBH polymorphisms and PD risk included seven [28-33] studies involving a total of 3482 cases and 4086 controls, including four for rs1611115 [28-31], two for rs2519152 [32, 33], and one for rs732833 [31]. The analysis results showed that no associations between a collection of all three DBH polymorphisms with susceptibility to PD was observed in three genetic patterns (allelic model: $P=0.899$, dominant model: $P=0.994$, and recessive model: $P=0.767$, shown in Fig. $2 \mathrm{~b}$ and Table 3 ). From the viewpoint of each DBH locus, a lack of association was also found between the polymorphisms of two loci and PD risk in more than one study (rs1611115: allelic model: $P=$ 0.742, dominant model: $P=0.787$, recessive model: $P=0.971$; rs2519152: allelic model: $P=$ 0.612 , dominant model: $P=0.577$, recessive model: $P=0.655$ ) (Table 3 ). In subgroup analysis by ethnicity, no association between the rs 1611115 polymorphism and PD development was observed among Caucasians (allelic model: $P=0.575$, dominant model: $P=0.631$, recessive model: $P=0.582$ ), but the association was statistically significant in Asians, represented by only one study under the allelic and dominant genetic models (allelic model: OR $=1.814$, 95\% CI: $1.167-2.821, P=0.008$, dominant model: $\mathrm{OR}=1.979,95 \% \mathrm{CI}: 1.119-3.498, P=$ 0.019 , recessive model: $P=0.078$ ) (Table 4). In addition, the rs732833 polymorphism, which presented in only one study, was also not associated with the risk of PD under any of the three genetic models (allelic model: $P=0.416$, dominant model: $P=0.523$, recessive model: $P=0.416$, shown in Table 3 ). In summary, the above results suggested that no associations exists between the DBH rs1611115, rs2519152, and rs732833 polymorphisms individually or in combination with the risk of developing PD. 
Cell Physiol Biochem 2018;51:411-428

\begin{tabular}{ll|l} 
and Biochemistry & $\begin{array}{l}\text { DOl: 10.1159/000495238 } \\
\text { Published online: } 17 \text { November } 2018\end{array}$ & $\begin{array}{l}\text { O 2018 The Author(s). Published by S. Karger AG, Basel } \\
\text { www.karger.com/cpb }\end{array}$ \\
\cline { 2 - 4 }
\end{tabular}

Tang et al.: DBH Polymorphisms and Alzheimer's Disease, Parkinson's Disease and

Schizophrenia

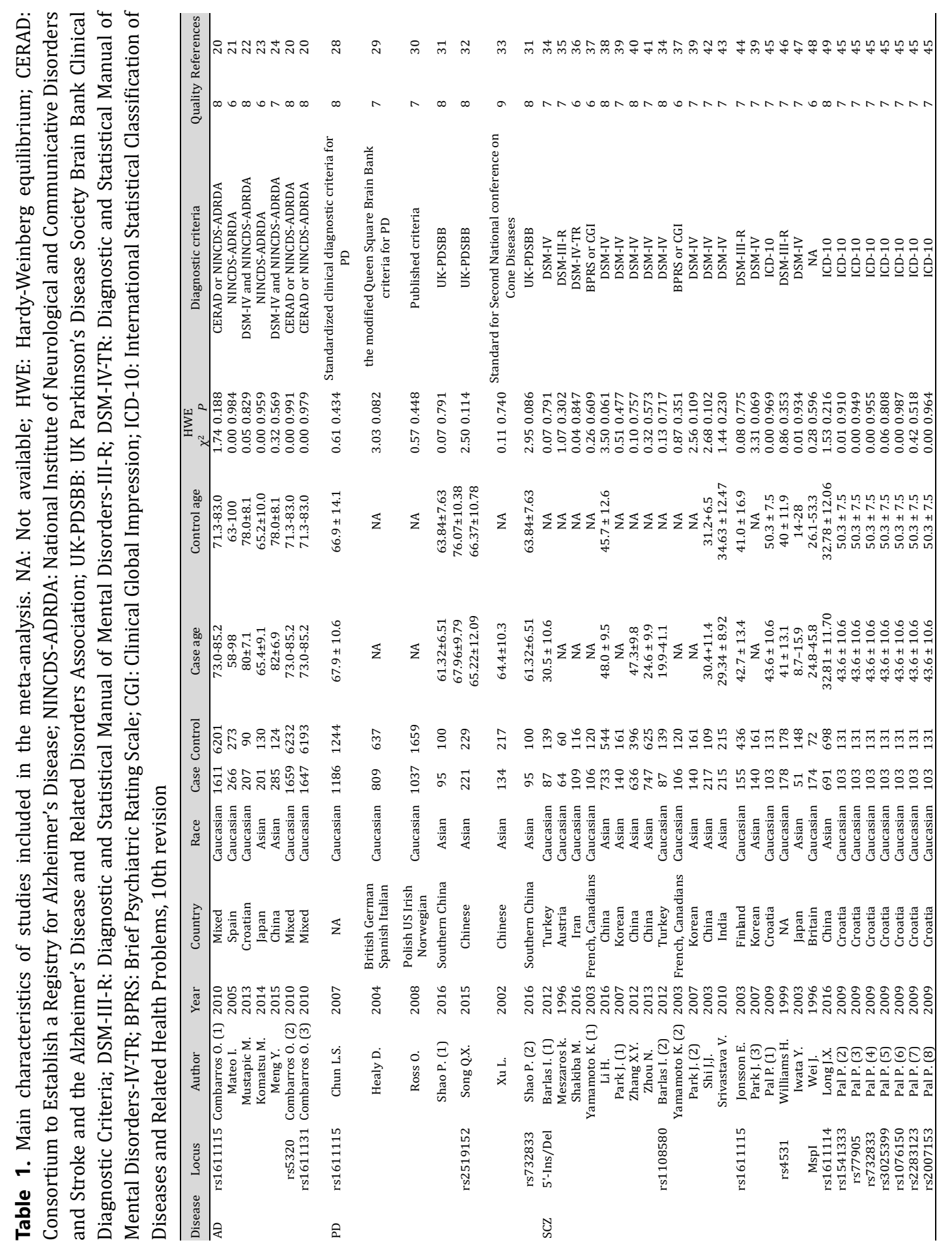

Association between DBH and SCZ

In this retrospective analysis, a total of twenty-seven studies involving 4406 cases and 4148 controls, including eight with the 5'-Ins/Del polymorphism [34-41], five with the rs1108580 polymorphism [34, 37, 39, 42, 43], three with the rs1611115 polymorphism [39, $44,45]$, two with the rs4531polymorphism [46, 47], and one each with the other nine loci, were utilized to study the association of DBH polymorphisms and SCZ risk. Our meta-analysis did not reveal any significant association between a collection of DBH polymorphisms and 


\section{Cellular Physiology Cell Physiol Biochem 2018;51:411-428

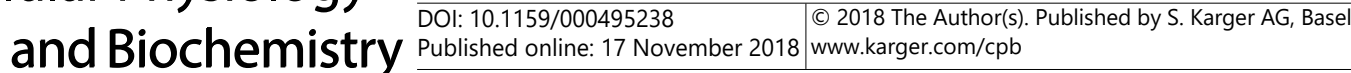 \\ Tang et al.: DBH Polymorphisms and Alzheimer's Disease, Parkinson's Disease and \\ Schizophrenia}

the development of SCZ under three genetic models (allelic model: $P=0.342$, dominant model: $P=0.563$, and recessive model: $P=0.312$ ) (Fig. $2 \mathrm{c}$ and Table $3)$. For four loci presenting in multiple studies, statistical results showed that their polymorphisms were not linked to the risk of developing SCZ (5'-Ins) Del: allelic model: $P=0.563$, dominant model: $P=0.445$, recessive model: $P$ $=0.906$; rs1108580: allelic model: $P$ $=0.750$, dominant model: $P=0.967$, recessive model: $P=0.552$; rs1611115: allelic model: $P=0.684$, dominant model: $P=0.830$, recessive model: $P=0.511$; and rs4531: allelic model: $P=0.279$, dominant model: $P=0.443$, recessive model: $P=0.268$ ) (Table 3). Subgroup analysis by ethnicity further suggested no association between polymorphisms of these loci and SCZ risk in Caucasians or Asians (Table 4). In addition, among nine loci presenting in only one study each, the polymorphisms of seven loci, including MspI, rs1611114, rs1541333, rs77905, rs732833, rs3025399 and rs1076150, showed no association with the risk of SCZ under any of the three genetic comparisons (Table $3)$. On the other hand, the analysis results indicated that the rs 2283123 polymorphism could significantly reduce susceptibility to SCZ in the allelic (OR $=0.285,95 \%$ CI: $0.095-0.862, P$ $=0.026)$ and dominant (OR $=0.290,95 \%$ CI: 0.094-0.897, $P=0.032)$ models but not in the recessive $(P=0.597)$ model, and the DBH rs2007153 polymorphism significantly increased the risk of developing SCZ under all three models (allelic model: $\mathrm{OR}=2.196,95 \% \mathrm{CI}=1.506$ 3.200, $P=0.000$; dominant model: $\mathrm{OR}=2.985,95 \% \mathrm{CI}=1.465-6.084, P=0.003$; recessive model: OR $=2.729,95 \%$ CI: $1.548-4.812, P=0.001$ ). In summary, the DBH rs2283123 and rs2007153 polymorphisms might influence SCZ risk, but the DBH 5'-Ins/Del, rs1108580, rs1611115, and rs4531 polymorphisms and the combination of all 13 DBH loci were not associated with the risk of SCZ development.

Association of $D B H$ with diseases with neurodegenerative features, including $A D, P D$, and SCZ

In this systematic analysis, a total of 41 studies involving 10506 cases and 15083 controls, including seven on AD [20-24], seven on PD [28-33], and twenty-seven on SCZ [3449], were used in combination to investigate the association between a combination of all the available DBH polymorphisms and the development of diseases with neurodegenerative features, including AD, PD and SCZ. The combined results showed a lack of association between them under three genetic models (allelic model: $P=0.330$, dominant model: $P=$ 0.755 , and recessive model: $P=0.509$, shown in Fig. $2 \mathrm{~d}$ and Table 3 ). In subgroup analysis by ethnicity, no associations of the sixteen DBH polymorphisms with the risks of these three diseases were found among either Caucasians (allelic model: $P=0.640$, dominant model: $P=$ 0.741 , and recessive model: $P=0.875$ ) or Asians (allelic model: $P=0.426$, dominant model: $P$ $=0.524$, and recessive model: $P=0.515$ ) (Table 4). In summary, the previously reported DBH polymorphisms did not have any cumulative effect on the susceptibility to diseases with neurodegenerative features, including AD, PD and SCZ.

Table 2. Quality assessment scheme for the included literatures (Newcastle-Ottawa Scale)

\begin{tabular}{|c|c|c|c|c|c|c|c|c|c|}
\hline \multirow{2}{*}{$\begin{array}{l}\text { Disease } \\
\mathrm{AD}\end{array}$} & Author & Year & \multicolumn{2}{|c|}{$\begin{array}{l}\text { Selection } \\
\text { I II III IV }\end{array}$} & \multirow{2}{*}{$\begin{array}{c}\text { Comparability } \\
\mathrm{V}\end{array}$} & \multicolumn{4}{|c|}{$\begin{array}{l}\text { Exposure } \\
\text { VI VII VIII Total }\end{array}$} \\
\hline & Combarros 0 . & 2010 & $* *$ & $*$ & & $*$ & $*$ & $*$ & 8 \\
\hline & Mateo I. & 2005 & & * & $*$ & * & * & * & 6 \\
\hline & Mustapic M. & 2013 & & * * & $* *$ & & $*$ & $*$ & 8 \\
\hline & Komatsu M. & 2014 & & * & $*$ & $*$ & * & * & 6 \\
\hline & Meng Y. & 2015 & $* *$ & * & $*$ & $*$ & * & $*$ & 7 \\
\hline \multirow[t]{6}{*}{ PD } & Chun L.S. & 2007 & $*$ & * * & $* *$ & & * & $*$ & 8 \\
\hline & Healy D. & 2004 & $* *$ & & $* *$ & & * & $*$ & 7 \\
\hline & Ross 0. & 2008 & & * & $* *$ & $*$ & $*$ & * & 7 \\
\hline & Shao P. & 2016 & $* *$ & * & $* *$ & * & * & * & 8 \\
\hline & Song Q.X. & 2015 & $* *$ & $*$ & $* *$ & $*$ & $*$ & $*$ & 8 \\
\hline & Xu L. & 2002 & $* *$ & $* *$ & $* *$ & $*$ & * & * & 9 \\
\hline \multirow[t]{16}{*}{ SCZ } & Barlas I. & 2012 & * & * & $* *$ & $*$ & * & * & 7 \\
\hline & Meszaros K. & 1996 & * & * & $* *$ & $*$ & $*$ & $*$ & 7 \\
\hline & Shakiba M. & 2016 & $* *$ & * & & $*$ & $*$ & * & 6 \\
\hline & Yamamoto K. & 2003 & $*$ & * & $*$ & * & * & $*$ & 6 \\
\hline & Li H. & 2016 & $* *$ & $* *$ & $*$ & $*$ & * & $*$ & 8 \\
\hline & Park J. & 2007 & $*$ & $* *$ & $*$ & $*$ & * & $*$ & 7 \\
\hline & Zhang X.Y. & 2012 & * & $* *$ & $* *$ & $*$ & * & * & 8 \\
\hline & Zhou N. & 2013 & * & * & $* *$ & $*$ & $*$ & $*$ & 7 \\
\hline & Shi J.J. & 2003 & * & $* *$ & $* *$ & $*$ & $*$ & * & 8 \\
\hline & Srivastava V. & 2010 & * & & $* *$ & $*$ & $*$ & * & 7 \\
\hline & Jonsson E. & 2003 & $*$ & & $* *$ & $*$ & $*$ & $*$ & 7 \\
\hline & Pal P. & 2009 & * & * & $*$ & $*$ & $*$ & * & 7 \\
\hline & Williams H. & 1999 & * & & $* *$ & $*$ & $*$ & * & 7 \\
\hline & Iwata Y. & 2003 & & & $* *$ & $*$ & $*$ & * & 7 \\
\hline & Wei J. & 1996 & & & $*$ & $*$ & $*$ & $*$ & 6 \\
\hline & Long J.X. & 2016 & $* *$ & & $* *$ & $*$ & $*$ & * & 8 \\
\hline
\end{tabular}

\section{:}


Tang et al.: DBH Polymorphisms and Alzheimer's Disease, Parkinson's Disease and

Schizophrenia

\section{Heterogeneity analysis}

In the abovementioned meta-analysis, high heterogeneity was found in analyses of the associations of the collection of DBH polymorphisms with PD risk (allelic model: $I^{2}=75.0 \%$; dominant model: $I^{2}=69.5 \%$; recessive model: $I^{2}=56.7 \%$ ) (shown in Table 3). In addition, significant heterogeneity was also observed in the investigation of correlations between both DBH rs1611115 (allelic model: $I^{2}=80.8 \%$, dominant model: $I^{2}=71.2 \%$ and recessive model: $I^{2}=76.4 \%$ ) and rs2519152 (allelic model: $I^{2}=86.6 \%$ and dominant model: $I^{2}=87.7 \%$ ) and PD risk. Meta-regression analysis was performed to explore whether the source of the abovementioned between-study heterogeneity was due to the publication year, ethnicity, diagnostic criteria, NOS score or sample size. Statistical results from the meta-regression are

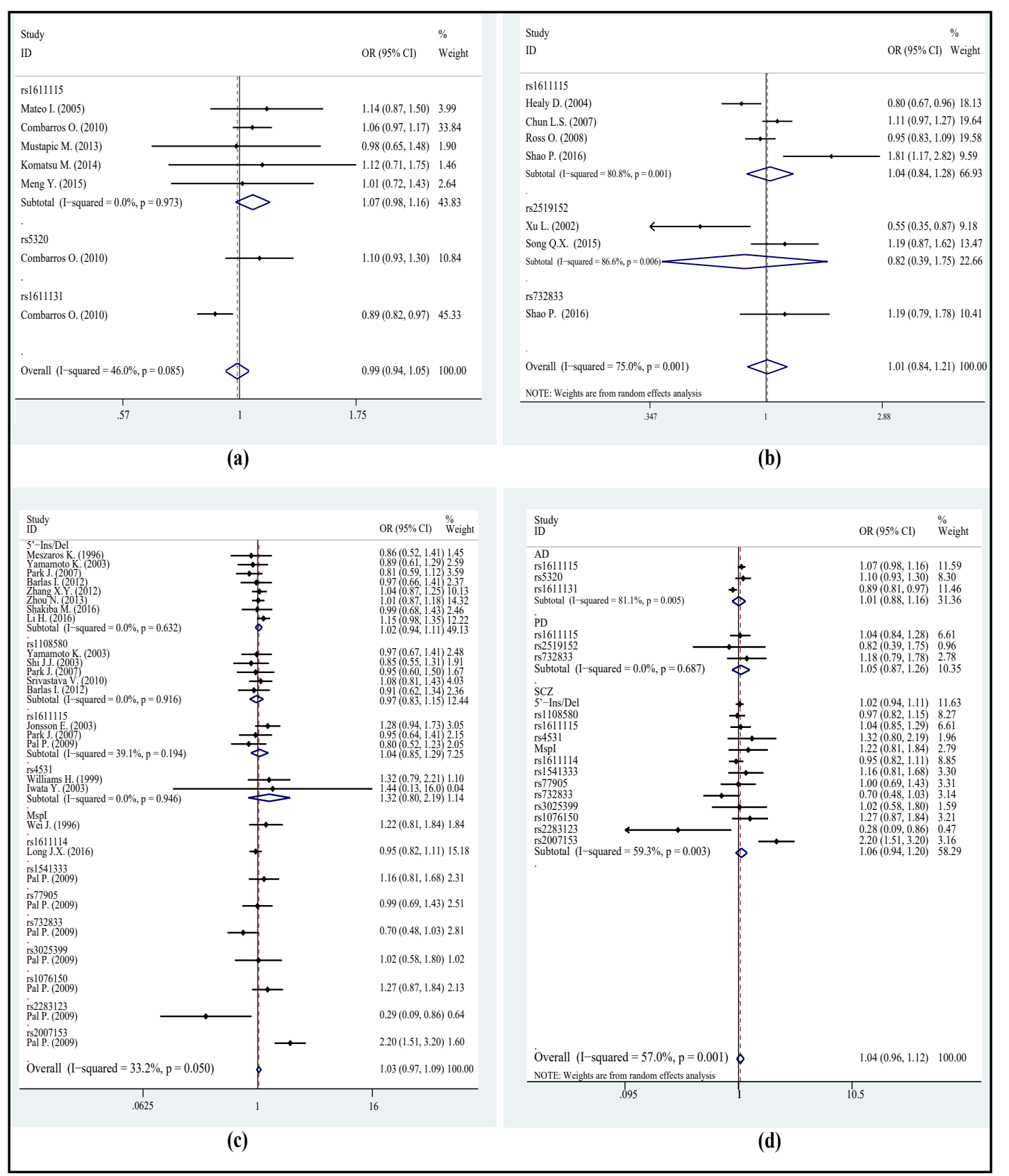

Fig. 2. Forest plots of the association between combined DBH polymorphisms and the risks of Alzheimer's disease (a), Parkinson's disease (b), schizophrenia (c) and all the three diseases (d) in the allelic model. 
Cell Physiol Biochem 2018;51:411-428

\begin{tabular}{l|l}
\hline DOI: $10.1159 / 000495238$ & ( 2018 The Author(s). Published by S. Karger AG, Basel
\end{tabular} and Biochemistry

Tang et al.: DBH Polymorphisms and Alzheimer's Disease, Parkinson's Disease and

Schizophrenia

displayed in Table S2. However, no factors could eliminate or reduce the heterogeneity to an acceptable level (all $P$-regression $>0.05$ ).

\section{Sensitivity analysis and publication bias}

Sensitivity analysis showed that the pooled ORs were not significantly altered for the DBH rs1611115, 5'-Ins/Del, and rs1108580 polymorphisms presenting in more than three studies on AD, PD and SCZ when all the included studies were excluded one by one, which indicated that our results were robust and reliable (data not shown). According to the shapes

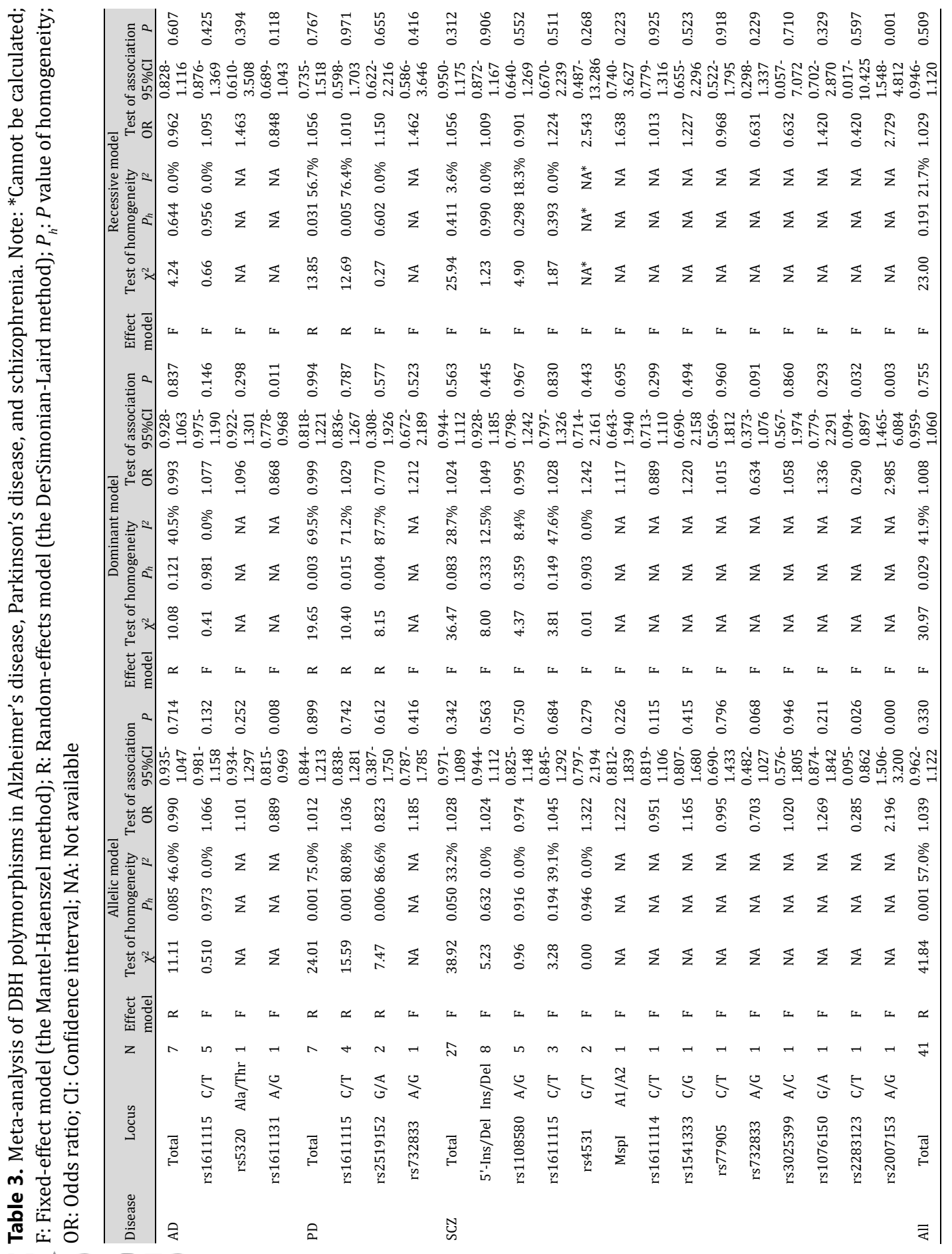




\section{Cellular Physiology Cell Physiol Biochem 2018;51:411-428

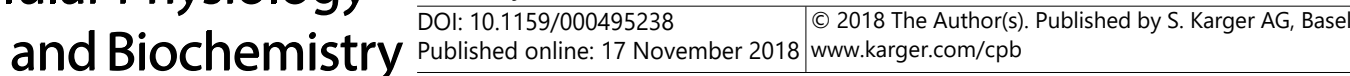 \\ Tang et al.: DBH Polymorphisms and Alzheimer's Disease, Parkinson's Disease and \\ Schizophrenia}

Table 4. Subgroup analysis of DBH polymorphisms on Alzheimer's disease, Parkinson's disease, schizophrenia by ethinicity. Note: F: Fixed-effect model (the Mantel-Haenszel method); R: Random-effects model (the DerSimonian-Laird method); $P_{h}: P$ value of homogeneity; OR: Odds ratio; CI: Confidence interval; NA: Not available

\begin{tabular}{|c|c|c|c|c|c|c|c|c|c|c|c|c|c|c|c|c|c|c|c|c|c|c|c|c|}
\hline \multirow{3}{*}{ Disease } & \multirow{3}{*}{\multicolumn{2}{|c|}{ Locus }} & \multirow{3}{*}{ N Population } & \multirow{3}{*}{$\begin{array}{l}\text { Effect } \\
\text { model }\end{array}$} & \multicolumn{6}{|c|}{ Allelic model } & \multicolumn{7}{|c|}{ Dominant model } & \multirow{3}{*}{$\begin{array}{l}\text { Effect } \\
\text { model }\end{array}$} & \multicolumn{6}{|c|}{ Recessive model } \\
\hline & & & & & \multicolumn{3}{|c|}{$\begin{array}{c}\text { Test of } \\
\text { homogeneity }\end{array}$} & \multicolumn{3}{|c|}{ Test of association } & \multirow{2}{*}{$\begin{array}{l}\text { Effect } \\
\text { model }\end{array}$} & \multicolumn{3}{|c|}{$\begin{array}{c}\text { Test of } \\
\text { homogeneity }\end{array}$} & \multicolumn{3}{|c|}{ Test of association } & & \multicolumn{3}{|c|}{$\begin{array}{c}\text { Test of } \\
\text { homogeneity }\end{array}$} & \multicolumn{3}{|c|}{ Test of association } \\
\hline & & & & & $x^{2}$ & $P_{h}$ & $I^{2}$ & OR & $95 \% \mathrm{Cl}$ & $P$ & & $x^{2}$ & $P_{h}$ & $I^{2}$ & OR & $95 \% \mathrm{Cl}$ & $P$ & & $x^{2}$ & $P_{h}$ & $I^{2}$ & OR & $95 \% \mathrm{CI}$ & $P$ \\
\hline \multirow[t]{2}{*}{$\mathrm{AD}$} & rs1611115 & $\mathrm{C} / \mathrm{T}$ & 3 Caucasian & $\mathrm{F}$ & 0.38 & 0.825 & $0.0 \%$ & 1.068 & $\begin{array}{l}0.979- \\
1.165\end{array}$ & 0.141 & $\mathrm{~F}$ & 0.27 & 0.874 & $0.0 \%$ & 1.082 & $\begin{array}{l}0.975- \\
1.202\end{array}$ & 0.139 & $\mathrm{~F}$ & 0.300 & 0.862 & $0.0 \%$ & 1.079 & $\begin{array}{l}.854- \\
1.364\end{array}$ & 0.523 \\
\hline & & & 2 Asian & $\mathrm{F}$ & 0.11 & 0.741 & $0.0 \%$ & 1.050 & $\begin{array}{l}0.799- \\
1.381\end{array}$ & 0.725 & $\mathrm{~F}$ & 0.05 & 0.824 & $0.0 \%$ & 1.025 & $\begin{array}{l}0.739- \\
1.422\end{array}$ & & & 0.210 & 0.644 & $0.0 \%$ & 1.267 & $\begin{array}{l}0.593- \\
2.706\end{array}$ & 0.541 \\
\hline \multirow[t]{2}{*}{ PD } & rs1611115 & $\mathrm{C} / \mathrm{T}$ & 3 Caucas & $\mathrm{R}$ & 8.14 & 0.0177 & $75.4 \%$ & 0.951 & $\begin{array}{l}0.797 . \\
1.134\end{array}$ & & $\mathrm{~F}$ & 62 & 0.0995 & $56.7 \%$ & 0.962 & $\begin{array}{l}0.822- \\
1.126\end{array}$ & & & 21 & 0.01 & $78.3 \%$ & 0.8 & $\begin{array}{l}0.509- \\
1.461\end{array}$ & 82 \\
\hline & & & 1 Asian & $\mathrm{F}$ & $\mathrm{NA}$ & $\mathrm{NA}$ & $\mathrm{NA}$ & 1.814 & $\begin{array}{l}1.167- \\
2.821\end{array}$ & 0.008 & $\mathrm{~F}$ & $\mathrm{NA}$ & NA & $\mathrm{NA}$ & 1.979 & $\begin{array}{l}1.119- \\
3.498\end{array}$ & 0.019 & $\mathrm{~F}$ & NA & $\mathrm{NA}$ & $\mathrm{NA}$ & 2.484 & $\begin{array}{l}0.903- \\
6.831\end{array}$ & 0.078 \\
\hline \multirow[t]{8}{*}{ SCZ } & 5'-Ins/Del In & Ins/Del & 14 Caucasian & $\mathrm{F}$ & 0.30 & 0.961 & $0.0 \%$ & 0.931 & $\begin{array}{l}0.764- \\
1.134\end{array}$ & 0.478 & & 0.12 & 0.989 & $0.0 \%$ & 0.878 & $\begin{array}{l}0.638- \\
1.207\end{array}$ & 422 & & .740 & 0.864 & $0.0 \%$ & 0.946 & $\begin{array}{l}0.687 . \\
1.302\end{array}$ & 0.732 \\
\hline & & & & $\mathrm{F}$ & 3.84 & 0.2792 & $22.0 \%$ & 1.045 & $\begin{array}{l}0.955- \\
1.144\end{array}$ & 0.337 & $R$ & & 0.0915 & $53.6 \%$ & 1.049 & $\begin{array}{l}0.854- \\
1.288\end{array}$ & 649 & & 300 & 0.961 & $0.0 \%$ & 1.026 & $\begin{array}{l}0.871- \\
1.208\end{array}$ & 0.758 \\
\hline & rs1108580 & $\mathrm{A} / \mathrm{G}$ & 2 Caucasian & $\mathrm{F}$ & 0.06 & 0.812 & $0.0 \%$ & 2.045 & $\begin{array}{l}0.723- \\
1.232\end{array}$ & 0.671 & $\mathrm{~F}$ & 0.07 & 0.786 & $0.0 \%$ & 0.820 & $\begin{array}{l}0.540- \\
1.245\end{array}$ & 0.353 & $\mathrm{~F}$ & 0.280 & 0.594 & $0.0 \%$ & 1.069 & $\begin{array}{l}0.678- \\
1.686\end{array}$ & 0.774 \\
\hline & & & $3 \quad$ Asian & $\mathrm{F}$ & 0.82 & 0.665 & $0.0 \%$ & 3.045 & $\begin{array}{l}0.804- \\
1.225\end{array}$ & 0.944 & $\mathrm{~F}$ & 3.16 & 0.2063 & $36.6 \%$ & 1.073 & $\begin{array}{l}0.827- \\
1.394\end{array}$ & 0.595 & $\mathrm{r}$ & 150 & 0.207 & $36.4 \%$ & 0.722 & $\begin{array}{l}30- \\
14\end{array}$ & 0.220 \\
\hline & rs1611115 & $\mathrm{C} / \mathrm{T}$ & 2 Caucasian & $\mathrm{R}$ & 2.95 & 0.0866 & $66.1 \%$ & 4.045 & $\begin{array}{l}0.663- \\
1.627\end{array}$ & 0.869 & $\mathrm{~K}$ & 2.76 & 0.097 & $63.7 \%$ & 1.061 & $\begin{array}{l}0.625- \\
1.801\end{array}$ & 0.827 & $T$ & 0.84 & 0.359 & $0.0 \%$ & 1.035 & $\begin{array}{l}0.522- \\
2.054\end{array}$ & 0.921 \\
\hline & & & Asian & $\mathrm{F}$ & $\mathrm{NA}$ & $\mathrm{NA}$ & $\mathrm{NA}$ & 5.045 & $\begin{array}{l}0.635- \\
1.415\end{array}$ & 0.794 & $\mathrm{~F}$ & NA & NA & NA & 0.838 & $\begin{array}{l}0.52 \\
1.34\end{array}$ & 0.460 & $\mathrm{~F}$ & IA & $\mathrm{NA}$ & $\mathrm{NA}$ & 2.358 & $\begin{array}{l}0.5 \\
9.6\end{array}$ & 0.231 \\
\hline & rs 4531 & $\mathrm{G} / \mathrm{T}$ & 1 Caucasian & F & $\mathrm{NA}$ & $\mathrm{NA}$ & $\mathrm{NA}$ & 6.045 & $\begin{array}{l}0.786- \\
2.211\end{array}$ & 0.296 & F & $\mathrm{NA}$ & NA & NA & 1.233 & $\begin{array}{l}0.698- \\
2.177\end{array}$ & 0.470 & F & $\mathrm{NA}$ & $\mathrm{NA}$ & NA & 2.543 & $\begin{array}{l}0.487- \\
13.286\end{array}$ & 0.268 \\
\hline & & & 1 Asian & F & $\mathrm{NA}$ & $\mathrm{NA}$ & $\mathrm{NA}$ & 7.045 & $\begin{array}{l}0.129 \\
16.002\end{array}$ & 0.769 & $\mathrm{~F}$ & $\mathrm{NA}$ & NA & $\mathrm{NA}$ & 1.440 & $\begin{array}{l}0.128- \\
16.225\end{array}$ & 0.768 & NA & NA & $\mathrm{NA}$ & NA & $\mathrm{NA}$ & $\mathrm{NA}$ & NA \\
\hline \multirow[t]{2}{*}{ All } & Total & & 25 Caucasian & $\mathrm{R}$ & 53.28 & 0.0015 & $55.0 \%$ & 8.045 & $\begin{array}{l}0.942- \\
1.103\end{array}$ & 0.640 & $\mathrm{~F}$ & 38.68 & 0.030 & $37.9 \%$ & 0.991 & $\begin{array}{l}0.940- \\
1.045\end{array}$ & 0.741 & F & 33.520 & 20.094 & $28.4 \%$ & 1.008 & $\begin{array}{l}0.909- \\
1.118\end{array}$ & 0.875 \\
\hline & & & 16 Asian & F & 21.14 & 0.1322 & $29.0 \%$ & 9.045 & $\begin{array}{l}0.962- \\
1.096\end{array}$ & 0.426 & F & 27.40 & 0.026 & $45.3 \%$ & 1.030 & $\begin{array}{l}0.941- \\
1.127\end{array}$ & 0.524 & $\mathrm{~F}$ & 11.270 & 70.665 & $0.0 \%$ & 1.043 & $\begin{array}{l}0.919- \\
1.183\end{array}$ & 0.515 \\
\hline
\end{tabular}

of Begg's funnel plots created by the trim and fill method, no asymmetric signal was observed under the allelic model (Fig. 3 shows the funnel plot for the allelic model to analyze the publication bias of the association of the DBH 5'-Ins/Del polymorphism with SCZ risk). Further quantitative tests also suggested no publication bias for these SNPs and the risks of AD, PD and SCZ (Table 5).

\section{Discussion}

As a member of the DA system, the DBH enzyme catalyzes the oxidative hydroxylation of

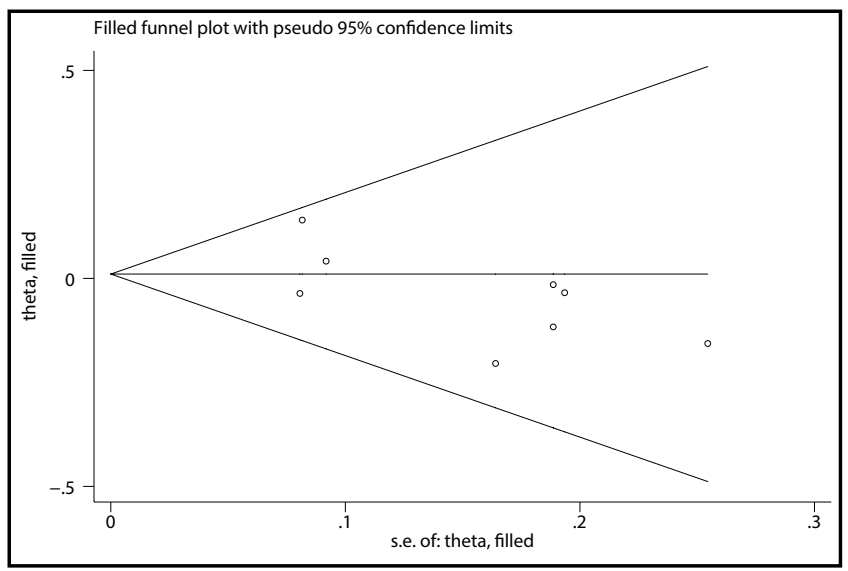

Fig. 3. Funnel plot for the allelic model to analyze the publication bias of the association between the DBH 5'-Ins/Del polymorphism and SCZ risk by the trim and fill method.

DA to NE in the CNS. A recent study reported the DBH crystal structure, revealing four domains (the DOMON (dopamine b-monooxygenase $\mathrm{N}$-terminal) domain, which forms a possible metal-binding site and a ligandbinding pocket; the catalytic $\mathrm{CuH}$ and $\mathrm{CuM}$ domains; and the C-terminal dimerization domain), providing new molecular insights into the catalytic mechanism, as well as the destructive disorders of both physiological and neurological origin of the DBH enzyme and the DA system [60]. On the other hand, the enzymatic activity and plasma level of DBH show wide interindividual

Table 5. Reported results of Begg's test to assess risk of publication bias on DBH polymorphisms and Alzheimer's disease, Parkinson's disease, and schizophrenia. Note: $P_{\text {-Beg: }}: P$ value of the Begg's test

\begin{tabular}{lccc}
\hline \multirow{2}{*}{ Disease } & \multirow{2}{*}{ Loci } & \multicolumn{2}{c}{ Test for Publication bias } \\
& & $\mathrm{N}$ & $P_{\text {-Begg }}$ \\
\hline $\mathrm{AD}$ & $\mathrm{rs} 1611115$ & 5 & 0.806 \\
$\mathrm{PD}$ & rs1611115 & 4 & 1.000 \\
$\mathrm{SCZ}$ & 5 '-Ins/Del & 8 & 0.266 \\
& rs1108580 & 5 & 0.221 \\
\hline
\end{tabular}




\section{Cellular Physiology Cell Physiol Biochem 2018;51:411-428 \begin{tabular}{ll|l} 
O 2018 The Author(s). Published by S. Karger AG, Basel \\
and Biochemistry 10.1159/000495238
\end{tabular} Tang et al.: DBH Polymorphisms and Alzheimer's Disease, Parkinson's Disease and Schizophrenia}

effects of DBH rs1611115 and rs6271 on decreased pDBH activity among AD patients [22]; the effect of rs1611115 on pDBH activity in SCZ was also confirmed by Sun Z.L. et al. (2017) [61]. Moreover, numerous studies have demonstrated that variants of the DBH gene have a significant influence on the cognitive phenotypes of neurological diseases. For example, Shao P. et al. (2016) suggested that abnormal cognitive states of PD patients are linked to the DBH rs1611115 variant among the Chinese Han population [31], and the rs1611115 and rs1108580 polymorphisms are significantly correlated with the degree of cognitive impairment in SCZ patients [61]. This evidence suggests that DBH SNPs could be a possible mechanism underlying the progression of AD, PD and SCZ. However, according to our results, DBH polymorphisms might not correlate with the developmental risk of these three diseases.

$\mathrm{AD}$ is a classical polygenic disease, but its pathogenic mechanism is still unclear. Many genes, such as apolipoprotein E (APOE) [62], triggering receptor expressed on myeloid cells 2 (TREM2) [63], and methylene tetrahydrofolate reductase (MTHFR) [64], in combination with environmental factors result in a network of interplay in AD development. DBH catalyzes the oxidative hydroxylation of DA to $\mathrm{NE}$, and recent evidence indicated that $\mathrm{NE}$ is not only a risk factor but also an actual etiological factor of AD [22]. We collected seven studies on the association of DBH polymorphisms at three loci (rs1611115, rs5320, and rs1611131) with the risk of $\mathrm{AD}$. The analysis results indicated that polymorphisms of these three loci were not associated with $\mathrm{AD}$ risk. Although the rs5320 polymorphism might not influence the disease susceptibility and needs to be further evaluated due to a low number of studies being included in the analysis, the conclusion that the rs1611115 polymorphism had no effect on the risk of $A D$ in this retrospective analysis should be quite robust because all five case-control studies included produced negative results (Combarros O. et al. (2010) [20], Mateo I. et al. (2006) [21], Mustapic M. et al. (2013) [22], Komatsu M. et al. (2014) [23], and Meng Y. et al. (2015) [24]). It should be noted that the negative result reported in the study by Combarros 0 . et al. included in this meta-analysis is discrepant with the positive result in the original publication due to an OR being adjusted by the synergistic factors that the authors utilized (sample source, age, sex and APOE $\varepsilon 4$ genotype) [20], but we estimated this association using rough allelic or genotypic data. On the other hand, Combarros 0. et al. also found that the correlation between the rs 1611115 allele and AD risk were nearly restricted to men [20]. In addition, the interaction between the presence of DBH rs1611115 and the TT genotype of IL1A rs1800587 was also found in the original publication, contributing to the determination of susceptibility to AD [20]. These results suggested that the role of the DBH rs1611115 variant might be influenced by other synergistic factors, such as age, gender and gene-gene interactions, in AD development. The rs1611131 polymorphism was statistically associated with a decreased risk of AD development in the allelic and dominant models but not in the recessive model. The data for this locus also originated from the study by Combarros 0 . et al., and our result was inconsistent with their negative result, possibly due to the similar confounding adjustment based on a small sample size. Furthermore, our study further illustrated that a combination of polymorphisms of the DBH three loci was not associated with AD risk, indicating that the previously identified DBH SNPs had no cumulative effect on the susceptibility to AD. However, the currently available evidence cannot prove that DBH polymorphisms are independent, risk-free factors underlying the development of AD.

PD is another neurodegenerative disorder commonly studied. Rare variants in monogenic forms have been shown to be connected with the disease at the gene level [65]. Neuropathological analysis of PD indicates that the retrogression of dopaminergic neurons in the substantia nigra leads to a DA deficiency in the corpus striatum [3]. The DBH enzyme is an important member of the DA system, and evidence has shown that under certain conditions, DBH can influence the NE levels in the brain [22]. In addition, previous studies found altered DBH activity in cerebrospinal fluid (CSF) [22], also suggesting that DBH might participate in the pathological mechanism of PD. However, little is known about how the DBH gene modulates DBH enzymatic activity as well as NE levels and further determines the retrogression of dopaminergic neurons in the development and progression of PD. Over 


\section{Cellular Physiology Cell Physiol Biochem 2018;51:411-428 and BiOChemistry \begin{tabular}{l|l} 
DOI: 10.1159/000495238 & Published online: 17 November 2018 \\
(c) 2018 The Author(s). Published by S. Karger AG, Basel \\
www.karger.com/cpb
\end{tabular} \\ Tang et al.: DBH Polymorphisms and Alzheimer's Disease, Parkinson's Disease and \\ Schizophrenia}

the past few decades, studies have investigated the correlation of DBH polymorphisms with PD risk, but they have displayed controversial results. Available data on the association between three SNPs (rs1611115, rs2519152, and rs732833) and PD risk were collected in our retrospective study. For rs1611115, combined results from all four of the studies included indicated that this SNP is not statistically associated with an increased PD risk, consistent with the results from two individual studies authored by Chun L.S. et al. (2007) [28] and Ross O. et al. (2008) [30] but not with those of the other two studies (Fig. 2B). In the other two original publications, Healy D. et al. (2004) reported that individuals carrying the homozygous DBH rs1611115 TT genotype have protection against PD [29]; conversely, Shao P. et al. (2016) recently found that this variant is likely associated with an increased susceptibility to PD [31]. Different genetic backgrounds from different races may possibly underlie this discrepancy because the former studies involved Caucasians, while the latter studies focused on the Asian population. A comparatively insufficient sample size may also be a probable cause underlying the discrepant results, as it may poorly represent the overall population. For another gene locus, rs2519152, statistical results based on two available studies also demonstrated no correlation between its polymorphism and the risk of developing PD (Fig. 2B and Table 3). This result is in accordance with the conclusion of the newest article by Song Q.X. et al. (2015) [32] but contradicts that of an earlier study by $\mathrm{Xu}$ L. et al. (2002) [33], which suggested a protective role of DBH rs2519152 minor variants against the development of PD [33] (Fig. 2B). Both studies were restricted to the Chinese Han population. Thus, further evaluating the link between this polymorphism and PD is necessary to achieve a definitive conclusion. For the third locus (rs732833) in this group, its polymorphism from one study was not associated with PD development (Table 3). In addition, our meta-analysis further illustrated a lack of association between a combination of the polymorphisms of these three loci and the risk of PD, also denoting that DBH SNPs might not have a comprehensive effect on the susceptibility to PD.

SCZ is one of the most severe chronic mental illnesses that presents with characteristic retrogression in the central nervous system (CNS) [66], and the neurodegenerative basis of SCZ remains a matter of debate. Previous studies have reported abnormal neuronal migration and clinical features of aberrant neurodevelopment in the form of soft neurological signs, which might suggest a neurodevelopmental mechanism for SCZ [67]. However, current evidence suggests that SCZ is a complex disorder with neuronal degeneration characteristics. On the basis of autopsy, gliosis was found in the brain tissues of SCZ patients [68], and more recently, Muraleedharan A. et al. (2015) reported substantial DNA damage in SCZ patients based on the detection of proteotoxic stress in cerebral cells [69], which both represent cardinal features of neurodegeneration hinting at neuron depletion. Compared to the classical neurodegenerative diseases $\mathrm{AD}$ and PD, the pathophysiological heterogeneity of SCZ might lead to diverse time course and treatment strategies. To date, we still have little knowledge about the neuropathology of SCZ [7], but the DA hypothesis is a leading theory underlying its etiology [70]. In 2014, Oliver H. et al. reported a presynaptic hyperdopaminergic abnormality in SCZ patients [71]. Cubells J.F. et al. (1998) [72] further implied that DBH activity and the CSF DBH protein level could be regarded as biomarkers of SCZ. Our retrospective study contained data available on the association between polymorphisms of thirteen loci and SCZ risk. Eight, five, three and two independent studies were collected in this meta-analysis containing polymorphisms of 5'-Ins/Del, rs1108580, rs1611115, and rs4531 on the development of SCZ, respectively. The conclusions of these studies on the genetic polymorphisms of these four loci shared considerable similarities. The combined result indicated that variants of these four loci were not statistically associated with SCZ susceptibility. Good consistency and no detectable heterogeneity among all the included studies indicate that our finding are robust (Fig. 2C and Table 3). Simultaneously, statistical analyses of the other seven SNPs (MspI, rs1541333, rs77905, rs732833, rs3025399, rs1076150 and rs1611114), each represented by only one study, demonstrated that they might not influence the susceptibility to SCZ, but these results need to be further confirmed (Fig. 2C and Table 3). On the other hand, Pal P. et al. (2009) found that the rs2007153 polymorphism showed significant allelic 


\section{Cellular Physiology Cell Physiol Biochem 2018;51:411-428

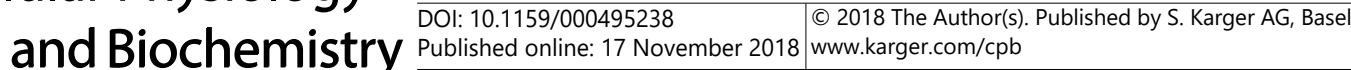 \\ Tang et al.: DBH Polymorphisms and Alzheimer's Disease, Parkinson's Disease and Schizophrenia}

and dominant associations with increased SCZ risk, which was consistent with our results. However, a correlation between rs2283123 and SCZ susceptibility was found under only the allelic model [45], while this association existed under all three genetic models in our metaanalysis. Only two DBH loci were found to be associated with SCZ risk, but the studies in which these loci were reported utilized relatively small sample sizes, and no other published studies have confirmed the association of these two loci with SCZ risk. This discrepancy might be explained by the "winner curse" phenomenon that usually occurs when using the candidate gene approach in which SNP loci are initially detected as associated factors but cannot be frequently identified by subsequent studies [73]. Future studies should focus on these two candidate target SNPs. Additionally, we further illustrated no statistically significant association between SCZ and the cumulative effect of available DBH SNPs.

Neurodegenerative diseases represent disorders resulting from the gradual loss of neuronal function or structure (or from neuronal death) [74]. In addition to classical neurodegenerative diseases, such as AD, PD, Huntington's disease (HD), amyotrophic lateral sclerosis (ALS) and Batten's disease (BD), some mental sicknesses, such as SCZ and depression, are newly reported to show the characteristics of neuronal degeneration $[69,75]$. Despite the common feature of gradual brain degeneration in patients with these diseases, a common underlying mechanism remains unclarified. In diseases such as AD, PD and SCZ, overphosphorylation of the tau protein is widely observed, leading to the abnormal accumulation and entanglement of nerve fibers, which further causes cerebral cell dysfunction, indicating that these diseases may share some pathogenic characteristics [7678]. On the other hand, based on the DA dysfunction and low DBH activity found in patients suffering from these diseases [27, 79, 80], genes of the DA system are considered vital candidate genetic targets for all neurodegenerative diseases. DBH, a critical member of the DA system, has been studied in association with the risks of neurodegenerative disease for a long time. We herein provide a comprehensive evaluation of the correlations of common genetic variants in candidate DBH gene loci with three diseases having neurodegenerative features, AD, PD and SCZ. In our findings, except for a few loci (rs1611131, rs2007153 and rs2283123) that might show correlation with neurodegenerative disorders, almost all the available SNPs were not associated with neurodegenerative diseases (Fig. 2D). In particular, DBH rs1611115, one of the most widely investigated DBH loci that was shown to regulate the activity and level of the DBH enzyme in numerous previous studies [22, 27, 81], displayed no association with any of the three diseases in our meta-analysis. Additionally, while the similar neural degeneration characteristics displayed by these three diseases, the fact that the cumulative statistical data displayed a lack of association between DBH loci and the risk of diseases suggest that DBH polymorphisms might not be risk factors underlying the development of disorders with neurodegenerative features. This statistical finding somewhat corresponds to the randomness in the distribution of negative associations between genetic polymorphisms and disease risk because if the results at each locus show a lack of association, their combination should indeed show nonsignificant correlation with the disease. These results could indicate that DBH polymorphisms may not be independent risk factors and thus may not be genetic markers for the risk of AD, PD and SCZ; however, they could still participate in the development of diseases with neurodegenerative characteristics by interacting with other genes.

Meta-analysis is a quantitative statistical analysis tool that can integrate the outcomes of independent studies and provide a more reliable conclusion. To our knowledge, no systematic study has comprehensively estimated the probable relationship between DBH SNPs and neurodegenerative disease. In our research, a thorough and meticulous search was performed to identify all available DBH polymorphisms, providing a comprehensive review of the association between DBH mutation and the risk of diseases with neurodegenerative characteristics, including AD, PD and SCZ. Both the independent role of a single DBH locus and its cumulative effect on these three types of neurological illness were analyzed in our meta-analysis, providing us with a better understanding of the gene-disease association from multiple viewpoints. However, some limitations of this study should also be recognized. 


\section{Cellular Physiology Cell Physiol Biochem 2018;51:411-428 \begin{tabular}{l|l|l} 
and Biochemistry & $\begin{array}{l}\text { DOI: 10.1159/000495238 } \\
\text { Published online: 17 November } 2018\end{array}$ & $\begin{array}{l}\text { @ } 2018 \text { The Author(s). Published by S. Karger AG, Basel } \\
\text { www.karger.com/cpb }\end{array}$
\end{tabular} \\ Tang et al.: DBH Polymorphisms and Alzheimer's Disease, Parkinson's Disease and \\ Schizophrenia}

First, the sample sizes of some of the included loci were small. It is worth noting that three significantly associated loci were presented in only one dataset, which might have led to a spurious correlation. Second, heterogeneity was detected in the association studies of some polymorphisms with PD, but we were unable to find the sources of heterogeneity in these polymorphisms according to the available concomitant factors. Third, previous studies suggested that the relationships of SNPs with AD, PD and SCZ might be affected by gender, onset age and carrying statuses of other genes. We could not conduct corresponding subgroup and stratification analyses [82] to further explore in-depth reasons for their association because of insufficient data. Therefore, the conclusions from the studies reviewed in this analysis should be interpreted with caution.

\section{Conclusion}

In conclusion, our comprehensive systemic review (a) suggested that most DBH polymorphisms of the currently available loci may not be risk factors for the neurological diseases AD, PD and SCZ and specifically (b) revealed a lack of association between the DBH rs1611115 polymorphism and the development of AD and between the 5'-Ins/Del, rs1108580, rs1611115 and rs4531 variants and the risk of developing SCZ; these results were supported by relatively large sample sizes and are thus robust conclusions. Our comprehensive systemic review also (c) showed that while the rs1611131 and rs2283123 polymorphisms could play a protective role in the risk of AD and SCZ, respectively, rs2007153 variants might be a risk factor for SCZ; however, these three loci were all reported by only one study each. While reliable conclusions might not be drawn for the associations of some DBH polymorphisms with PD due to either high heterogeneity between studies or having only a few case-control studies available for analysis, future well-designed studies with large sample sizes as well as gene-gene and gene-environment interactions are needed to confirm these conclusions.

\section{Acknowledgements}

This work was supported by the National Natural Science Foundation of China (31770774),the Provincial Major Project of Basic or Applied Research in Natural Science, Guangdong Provincial Education Department (2016KZDXM038), and the 2013 Sail Plan "The Introduction of the Shortage of Top-Notch Talent" Project (YueRenCaiBan [2014] 1). We also thank American Journal Experts (AJE) for their help in revising the English grammar.

\section{Disclosure Statement}

The authors declare no conflicts of interest.

\section{References}

1 Morrison JH, Hof PR: Life and death of neurons in the aging brain. Science 1997;278:412-419.

2 Lyness SA, Zarow C, Chui HC: Neuron loss in key cholinergic and aminergic nuclei in Alzheimer disease: a meta-analysis. Neurobiol Aging 2003;24:1-23.

3 McMillan PJ, White SS, Franklin A, Greenup JL, Leverenz JB, Raskind MA, Szot P: Differential response of the central noradrenergic nervous system to the loss of locus coeruleus neurons in Parkinson's disease and Alzheimer's disease. Brain Res 2011;1373:240-252.

4 Kircher TT, Thienel R: Functional brain imaging of symptoms and cognition in schizophrenia. Prog Brain Res 2005;150:299-308. 


\section{Cellular Physiology Cell Physiol Biochem 2018;51:411-428 \begin{tabular}{l|l|l|l|l|l}
\hline DOI: 10.1159/000495238 & 2018 The Author(s). Published by S. Karger AG, Basel
\end{tabular}

Tang et al.: DBH Polymorphisms and Alzheimer's Disease, Parkinson's Disease and

Schizophrenia

52016 Alzheimer's disease facts and figures. Alzheimers Dement 2016;12:459-509.

6 Sveinbjornsdottir S: The clinical symptoms of Parkinson's disease. J Neurochem 2016;139:318-324.

7 Brody H: Schizophrenia. Nature 2014;508:S1.

8 Global, regional, and national incidence, prevalence, and years lived with disability for 301 acute and chronic diseases and injuries in 188 countries, 1990-2013: a systematic analysis for the Global Burden of Disease Study 2013. Lancet 2015;386:743-800.

-9 Global, regional, and national incidence, prevalence, and years lived with disability for 310 diseases and injuries, 1990-2015: a systematic analysis for the Global Burden of Disease Study 2015. Lancet 2016;388:1545-1602.

10 Gandhi S, Wood NW: Genome-wide association studies: the key to unlocking neurodegeneration? Nat Neurosci 2010;13:789-794.

-11 Nishimura AL, Guindalini C, Oliveira JR, Nitrini R, Bahia VS, de Brito-Marques PR, Otto PA, Zatz M: Monoamine oxidase a polymorphism in Brazilian patients: risk factor for late-onset Alzheimer's disease? J Mol Neurosci 2005;27:213-217.

12 Dick FD, De Palma G, Ahmadi A, Osborne A, Scott NW, Prescott GJ, Bennett J, Semple S, Dick S, Mozzoni P, Haites N, Wettinger SB, Mutti A, Otelea M, Seaton A, Soderkvist P, Felice A: Gene-environment interactions in parkinsonism and Parkinson's disease: the Geoparkinson study. Occup Environ Med 2007;64:673-680.

13 Qiu HT, Meng HQ Song C, Xiu MH, Chen DC, Zhu FY, Wu GY, Kosten TA, Kosten TR, Zhang XY: Association between monoamine oxidase (MAO)-A gene variants and schizophrenia in a Chinese population. Brain Res 2009;1287:67-73.

14 Takehashi M, Tanaka S, Masliah E, Ueda K: Association of monoamine oxidase A gene polymorphism with Alzheimer's disease and Lewy body variant. Neurosci Lett 2002;327:79-82.

15 Singh M, Khan AJ, Shah PP, Shukla R, Khanna VK, Parmar D: Polymorphism in environment responsive genes and association with Parkinson disease. Mol Cell Biochem 2008;312:131-138.

-16 Gasso P, Bernardo M, Mas S, Crescenti A, Garcia C, Parellada E, Lafuente A: Association of A/G polymorphism in intron 13 of the monoamine oxidase B gene with schizophrenia in a Spanish population. Neuropsychobiology 2008;58:65-70.

17 Yan W, Zhao C, Sun L, Tang B: Association between polymorphism of COMT gene (Val158Met) with Alzheimer's disease: An updated analysis. J Neurol Sci 2016;361:250-255.

18 Zhang Y, Feng S, Nie K, Zhao X, Gan R, Wang L, Zhao J, Tang H, Gao L, Zhu R, Wang L, Zhang Y: Catechol-Omethyltransferase Val158Met polymorphism influences prefrontal executive function in early Parkinson's disease. J Neurol Sci 2016;369:347-353.

19 Lang UE, Puls I, Muller DJ, Strutz-Seebohm N, Gallinat J: Molecular mechanisms of schizophrenia. Cell Physiol Biochem 2007;20:687-702.

20 Combarros O, Warden DR, Hammond N, Cortina-Borja M, Belbin O, Lehmann MG, Wilcock GK, Brown K, Kehoe PG, Barber R, Coto E, Alvarez V, Deloukas P, Gwilliam R, Heun R, Kölsch H, Mateo I, Oulhaj A, AriasVásquez A, Schuur M: The dopamine $\beta$-hydroxylase -1021C/T polymorphism is associated with the risk of Alzheimer's disease in the Epistasis Project. BMC Med Genet 2010;11:162-171.

-21 Mateo I, Infante J, Rodríguez E, Berciano J, Combarros O, Llorca J: Interaction between dopamine betahydroxylase and interleukin genes increases Alzheimer's disease risk. J Neurol Neurosur PS 2006;77:278279.

22 Mustapic M, Presecki P, Pivac N, Mimica N, Hof PR, Simic G, Folnegovic-Smalc V, Muck-Seler D: Genotypeindependent decrease in plasma dopamine beta-hydroxylase activity in Alzheimer's disease. Prog Neuropsychoph 2013;44:94-99.

23 Komatsu M, Shibata N, Ohnuma T, Kuerban B, Tomson K, Toda A, Tagata Y, Nakada T, Shimazaki H, Arai H: Polymorphisms in the aldehyde dehydrogenase 2 and dopamine $\beta$ hydroxylase genes are not associated with Alzheimer's disease. J Neural Transm 2014;121:427-432.

24 Meng Y, Zhu YL: A study on the association between plasma dopamine beta-hydroxylase and Alzheimer's disease. Chin J Lab Diagn 2015;19:1505-1507.

25 Isobe K: Dopamine -beta-hydroxylase. Nihon Rinsho 2010;68:419-421.

-26 Kim CH, Zabetian CP, Cubells JF, Cho S, Biaggioni I, Cohen BM, Robertson D, Kim KS: Mutations in the dopamine beta-hydroxylase gene are associated with human norepinephrine deficiency. Am J Med Genet 2002;108:140-147. 


\section{Cellular Physiology Cell Physiol Biochem 2018;51:411-428 \begin{tabular}{l|l|l|l|l|}
\hline DOI: 10.1159/000495238 2018 The Author(s). Published by S. Karger AG, Basel & and Biochemistry
\end{tabular}

Tang et al.: DBH Polymorphisms and Alzheimer's Disease, Parkinson's Disease and

Schizophrenia

27 Cubells JF, Zabetian CP: Human genetics of plasma dopamine beta-hydroxylase activity: applications to research in psychiatry and neurology. Psychopharmacology (Berl) 2004;174:463-476.

28 Chun LS, Samii A, Hutter CM, Griffith A, Roberts JW, Leis BC, Mosley AD, Wander PL, Edwards KL, Payami H, Zabetian CP: DBH -1021C-->T does not modify risk or age at onset in Parkinson's disease. Ann Neurol 2007;62:99-101.

29 Healy DG, Abou-Sleiman PM, Ozawa T, Lees AJ, Bhatia K, Ahmadi KR, Wullner U, Berciano J, Moller JC, Kamm C, Burk K, Barrone P, Tolosa E, Quinn N, Goldstein DB, Wood NW: A functional polymorphism regulating dopamine beta-hydroxylase influences against Parkinson's disease. Ann Neurol 2004;55:443-446.

-30 Ross OA, Heckman MG, Soto AI, Diehl NN, Haugarvoll K, Vilarino-Guell C, Aasly JO, Sando S, Gibson JM, Lynch T, Krygowska-Wajs A, Opala G, Barcikowska M, Czyzewski K, Uitti RJ, Wszolek ZK, Farrer MJ: Dopamine $\beta$-hydroxylase $-1021 \mathrm{C}>\mathrm{T}$ association and Parkinson's disease. Parkinsonism Relat D 2008;14:544-547.

31 Shao P, Yu YX, Bao JX: Association of Dopamine Beta-Hydroxylase (DBH) Polymorphisms with Susceptibility to Parkinson's Disease. Med Sci Monitor 2016;22:1617-1622.

32 Song QX, Li YY, Zhang XY: Relationship between Xinjiang Region Parkinson's Disease and the Interaction between Polymorphisms of Catechol-O-methyltransferase, Monoamine Oxidase B, Dopamine $\beta$-hydroxylase and Environmental Factors. Chin J Clin Neurosci 2015;23:497-508.

$33 \mathrm{Xu}$ L: Association analysis between dopamine metabilsm system genes and parkinson's disease. Fudan University, 2002.

34 Barlas IÖ, Semiz U, Erdal ME, Algül A, Ay OI, Ateş MA, Camdeviren H, Basoglu C, Herken H: Association between dopamine beta hydroxylase gene polymorphism and age at onset in male schizophrenia. Acta Neuropsychiatr 2012;24:176-182.

-35 Meszaros K, Lenzinger E, Fureder T, Hornik K, Willinger U, Stompe T, Heiden AM, Resinger E, Fathi N, Gerhard E, Fuchs K, Miller-Reiter E, Pfersmann V, Sieghart W, Aschauer HN, Kasper S: Schizophrenia and the dopamine-beta-hydroxylase gene: results of a linkage and association study. Psychiatr Genet 1996;6:17-22.

36 Shakiba M, Hashemi M, Shahrabadi S, Rezaei M, Taheri M: Lack of Association Between Dopamine BetaHydroxylase (DBH) 19-bp Insertion/Deletion Polymorphism and Risk of Schizophrenia. Iran J Psychiatry 2016;11:239-243.

37 Yamamoto K, Cubells JF, Gelernter J, Benkelfat C, Lalonde P, Bloom D, Lal S, Labelle A, Turecki G, Rouleau GA, Joober R: Dopamine beta-hydroxylase (DBH) gene and schizophrenia phenotypic variability: a genetic association study. Am J Med Genet B 2003;117b:33-38.

38 Hui L, Han M, Huang XF, Ye MJ, Zhang X, He JC, Lv MH, Soares JC, Zhang XY: Association between DbetaH 5'-insertion/deletion polymorphism and cognition in patients with chronic schizophrenia. J Clin Psychiatry 2016;77:379-385.

39 Park JK, Kim JW, Lee HJ, Chung JH, Ha EY, Oh DJ, Song JY: Dopamine beta-hydroxylase gene polymorphisms and psychotic symptoms in schizophrenia. Am J Med Genet B 2007;144b:944-945.

40 Zhang XY, Chen DC, Xiu MH, Hui L, Liu H, Luo X, Zuo L, Zhang H, Kosten TA, Kosten TR: Association of functional dopamine-beta-hydroxylase (DBH) $19 \mathrm{bp}$ insertion/deletion polymorphism with smoking severity in male schizophrenic smokers. Schizophr Res 2012;141:48-53.

-41 Zhou N, Yu Q, Li X, Yu Y, Kou C, Li W, Xu H, Luo X, Zuo L, Kosten TR, Zhang XY: Association of the dopamine $\beta$-hydroxylase $19 \mathrm{bp}$ insertion/deletion polymorphism with positive symptoms but not tardive dyskinesia in schizophrenia. Hum Psychopharmclin 2013;28:230-237.

42 Shi JJ, Fan CH, Deng HH, Guo YB, Feng RM, Han HY, Yang Q, Ma C: The G444A Polymorphism in the Dopamine- $\beta$-Hydroxylase Gene May Be Associated with Neuroleptic-Induced Tardive Dyskinesia in Chronic Schizophrenia. Acad J Guangzhou Med Coll 2004;32:32-35.

-43 Srivastava V, Deshpande SN, Thelma BK: Dopaminergic pathway gene polymorphisms and genetic susceptibility to schizophrenia among north Indians. Neuropsychobiology 2010;61:64-70.

44 Jonsson EG, Abou Jamra R, Schumacher J, Flyckt L, Edman G, Forslund K, Mattila-Evenden M, Rylander G, Asberg M, Bjerkenstedt L, Wiesel FA, Propping P, Cichon S, Nothen MM, Sedvall GC: No association between a putative functional promoter variant in the dopamine beta-hydroxylase gene and schizophrenia. Psychiatr Genet 2003;13:175-178. 


\section{Cellular Physiology Cell Physiol Biochem 2018;51:411-428 \begin{tabular}{l|l|l} 
and Biochemistry 2018 The Author(s). Published by S. Karger AG, Basel & $\begin{array}{l}\text { DOl: 10.1159/000495238 } \\
\text { Published }\end{array}$
\end{tabular}

Tang et al.: DBH Polymorphisms and Alzheimer's Disease, Parkinson's Disease and

Schizophrenia

45 Pal P, Mihanovic M, Molnar S, Xi H, Sun G, Guha S, Jeran N, Tomljenovic A, Malnar A, Missoni S, Deka R, Rudan P: Association of tagging single nucleotide polymorphisms on 8 candidate genes in dopaminergic pathway with schizophrenia in Croatian population. Croat Med J 2009;50:361-369.

46 Williams HJ, Bray N, Murphy KC, Cardno AG, Jones LA, Owen MJ: No evidence for allelic association between schizophrenia and a functional variant of the human dopamine $\beta$-hydroxylase gene (DBH). Am J Med Genet B 1999;88:557-559.

47 Iwata Y, Matsumoto H, Minabe Y, Osada N, Nakamura K, Sekizawa T, Suzuki K, Sekine Y, Takei N, Mori N: Early-onset schizophrenia and dopamine-related gene polymorphism. Am J Med Genet B 2003;116b:23-26.

$\$ 48$ Wei J, Ramchand CN, Hemmings GP: A study of the relationship between the DBH activity in serum and a MspI polymorphic site in intron 9 of the human DBH gene in schizophrenia. Schizophr Res 1996;22:77-80.

49 Long J, Huang G, Liang B, Ling W, Guo X, Jiang J, Su L: The dopamine beta-hydroxylase gene polymorphism rs1611114 is associated with schizophrenia in the Chinese Zhuang but not Chinese Han population. Mol Genet Genomics 2016;291:1813-1821.

50 Deeks JJ, Dinnes J, D’Amico R, Sowden AJ, Sakarovitch C, Song F, Petticrew M, Altman DG: Evaluating nonrandomised intervention studies. Health Technol Assess 2003;7:iii-x, 1-173.

51 Alexander RA, Scozzaro MJ, Borodkin LJ: Statistical and empirical examination of the chi-square test for homogeneity of correlations in meta-analysis. Psychol Bull 1989;106:329-331.

52 Mantel N, Haenszel W: Statistical aspects of the analysis of data from retrospective studies of disease. J Natl Cancer Inst 1959;22:719-748.

53 Schmidt FL, Oh IS, Hayes TL: Fixed- versus random-effects models in meta-analysis: model properties and an empirical comparison of differences in results. Br J Math Stat Psychol 2009;62:97-128.

54 Thompson SG, Higgins JP: How should meta-regression analyses be undertaken and interpreted? Stat Med 2002;21:1559-1573.

55 Bradburn MJ, Deeks JJ, Altman DG: Metan-An alternative meta-analysis command. Stata Technical Bulletin 1999;8.

56 Shaffer D: A participant's observations: preparing DSM-IV. Can J Psychiatry 1996;41:325-329.

-57 McKhann G, Drachman D, Folstein M, Katzman R, Price D, Stadlan EM: Clinical diagnosis of Alzheimer's disease: report of the NINCDS-ADRDA Work Group under the auspices of Department of Health and Human Services Task Force on Alzheimer's Disease. Neurology 1984;34:939-944.

58 Lyons KE, Pahwa R: Diagnosis and initiation of treatment in Parkinson's disease. Int J Neurosci 2011;121 Suppl 2:27-36.

59 Implementation of the International Statistical Classification of Diseases and Related Health Problems, Tenth Revision (ICD-10). Epidemiol Bull 1997;18:1-4.

60 Vendelboe TV, Harris P, Zhao Y, Walter TS, Harlos K, El Omari K, Christensen HE: The crystal structure of human dopamine beta-hydroxylase at 2.9 A resolution. Sci Adv 2016;2:e1500980.

61 Sun Z, Ma Y, Li W, He J, Li J, Yang X, Mao P, Cubells JF, Tang YL: Associations between the DBH gene, plasma dopamine beta-hydroxylase activity and cognitive measures in Han Chinese patients with schizophrenia. Schizophr Res 2018;193:58-63.

62 Namboori PK, Vineeth KV, Rohith V, Hassan I, Sekhar L, Sekhar A, Nidheesh M: The ApoE gene of Alzheimer's disease (AD). Funct Integr Genomics 2011;11:519-522.

63 Lill CM, Rengmark A, Pihlstrom L, Fogh I, Shatunov A, Sleiman PM, Wang LS, Liu T, Lassen CF, Meissner E, Alexopoulos P, Calvo A, Chio A, Dizdar N, Faltraco F, Forsgren L, Kirchheiner J, Kurz A, Larsen JP, Liebsch M, Linder J, Morrison KE, Nissbrandt H, Otto M, Pahnke J, Partch A, Restagno G, Rujescu D, Schnack C, Shaw CE, Shaw PJ, Tumani H, Tysnes OB, Valladares O, Silani V, van den Berg LH, van Rheenen W, Veldink JH, Lindenberger U, Steinhagen-Thiessen E, Teipel S, Perneczky R, Hakonarson H, Hampel H, von Arnim CAF, Olsen JH, Van Deerlin VM, Al-Chalabi A, Toft M, Ritz B, Bertram L: The role of TREM2 R47H as a risk factor for Alzheimer's disease, frontotemporal lobar degeneration, amyotrophic lateral sclerosis, and Parkinson's disease. Alzheimers Dement 2015;11:1407-1416.

64 Hua Y, Zhao H, Kong Y, Ye M: Association between the MTHFR gene and Alzheimer's disease: a metaanalysis. Int J Neurosci 2011;121:462-471.

65 Kalia LV, Lang AE: Parkinson's disease. Lancet 2015;386:896-912.

66 Olabi B, Ellison-Wright I, McIntosh AM, Wood SJ, Bullmore E, Lawrie SM: Are there progressive brain changes in schizophrenia? A meta-analysis of structural magnetic resonance imaging studies. Biol Psychiatry 2011;70:88-96. 


\section{Cellular Physiology Cell Physiol Biochem 2018;51:411-428 \begin{tabular}{l|l|l} 
and Biochemistry & $\begin{array}{l}\text { DOI: 10.1159/000495238 } \\
\text { Published online: 17 November } 2018\end{array}$ & $\begin{array}{l}\text { @ } 2018 \text { The Author(s). Published by S. Karger AG, Basel } \\
\text { www.karger.com/cpb }\end{array}$
\end{tabular} \\ Tang et al.: DBH Polymorphisms and Alzheimer's Disease, Parkinson's Disease and Schizophrenia}

67 Gupta S, Kulhara P: What is schizophrenia: A neurodevelopmental or neurodegenerative disorder or a combination of both? A critical analysis. Indian J Psychiatry 2010;52:21-27.

68 Harrison PJ: The neuropathology of schizophrenia. A critical review of the data and their interpretation. Brain 1999;122:593-624.

69 Muraleedharan A, Menon V, Rajkumar RP, Chand P: Assessment of DNA damage and repair efficiency in drug naive schizophrenia using comet assay. J Psychiatr Res 2015;68:47-53.

70 Van Os J, Kapur S: Schizophrenia. Lancet 2009;374:635-645.

71 Howes OD, Kapur S: A neurobiological hypothesis for the classification of schizophrenia: type A (hyperdopaminergic) and type B (normodopaminergic). Br J Psychiatry 2014;205:1-3.

-72 Cubells JF, van Kammen DP, Kelley ME, Anderson GM, O’Connor DT, Price LH, Malison R, Rao PA, Kobayashi K, Nagatsu T, Gelernter J: Dopamine beta-hydroxylase: two polymorphisms in linkage disequilibrium at the structural gene DBH associate with biochemical phenotypic variation. Hum Genet 1998;102:533-540.

73 Nakaoka H, Inoue I: Meta-analysis of genetic association studies: methodologies, between-study heterogeneity and winner's curse. J Hum Genet 2009;54:615-623.

74 Radi E, Formichi P, Battisti C, Federico A: Apoptosis and oxidative stress in neurodegenerative diseases. J Alzheimers Dis 2014;42:S125-152.

75 Brown GM, McIntyre RS, Rosenblat J, Hardeland R: Depressive disorders: Processes leading to neurogeneration and potential novel treatments. Prog Neuro-psychoph 2018;80:189-204.

76 Compta Y, Parkkinen L, Kempster P, Selikhova M, Lashley T, Holton JL, Lees AJ, Revesz T: The significance of alpha-synuclein, amyloid-beta and tau pathologies in Parkinson's disease progression and related dementia. Neurodegener Dis 2014;13:154-156.

77 Bosia M, Buonocore M, Guglielmino C, Pirovano A, Lorenzi C, Marcone A, Bramanti P, Cappa SF, Aguglia E, Smeraldi E, Cavallaro R: Saitohin polymorphism and executive dysfunction in schizophrenia. Neurol Sci 2012;33:1051-1056.

-78 Amemori T, Jendelova P, Ruzicka J, Urdzikova LM, Sykova E: Alzheimer's Disease: Mechanism and Approach to Cell Therapy. Int J Mol Sci 2015;16:26417-26451.

79 Ross JA, Gliebus G, Van Bockstaele EJ: Stress induced neural reorganization: A conceptual framework linking depression and Alzheimer's disease. Prog Neuro-psychoph 2018;85:136-151.

80 Ermine CM, Wright JL, Frausin S, Kauhausen JA, Parish CL, Stanic D, Thompson LH: Modelling the dopamine and noradrenergic cell loss that occurs in Parkinson's disease and the impact on hippocampal neurogenesis. Hippocampus 2018;28:327-337.

81 Zabetian CP, Anderson GM, Buxbaum SG, Elston RC, Ichinose H, Nagatsu T, Kim KS, Kim CH, Malison RT, Gelernter J, Cubells JF: A quantitative-trait analysis of human plasma-dopamine beta-hydroxylase activity: evidence for a major functional polymorphism at the DBH locus. Am J Hum Genet 2001;68:515-522.

-82 Lin S, Liu X, Yao B, Huang Z: Controlling for confounding factors and revealing their interactions in genetic association meta-analyses: a computing method and application for stratification analyses. Oncotarget 2018;9:12125-12136. 